\title{
Minimum days dry to maximize milk yield in subsequent lactation
}

\author{
Melvin T. KUHN*, Jana L. HUTCHISON, H.D. NORMAN \\ Animal Improvement Programs Laboratory, Agricultural Research Service, USDA, Beltsville, \\ MD 20705-2350, USA \\ (Received 27 January 2005; accepted 27 May 2005)
}

\begin{abstract}
The objective of this research was to determine the effect of days dry (DD) on actual milk yield and to identify the minimum dry period length needed to maximize milk yield in the subsequent lactation. Field data collected through the U.S. dairy herd improvement association from January, 1997 to December, 2003 and extracted from the Animal Improvement Programs Laboratory national database were used for analysis. Actual lactation records calculated from test-day yields using the test-interval method were used in this study. The model for analysis included herd-year of calving, year-state-month of calving, previous lactation milk yield, age at calving, and DD as a categorical variable. Interactions were added to this model to determine if the effects of DD on subsequent lactation milk yield depended on previous lactation milk yield, age at calving, somatic cell score, or days open. Milk yield in the subsequent lactations was generally maximized with a 60 to 65 d dry period, regardless of parity. Days dry effects on milk yield were, for the most part, consistent across lactations, although dry periods $<35 \mathrm{~d}$ are somewhat more detrimental to milk yield after first lactation than after second and later lactations. Dry periods less than $20 \mathrm{~d}$ result in very pronounced losses in subsequent lactation yield. A short dry period $(<40 \mathrm{~d})$ for high producing cows that bred back early in lactation proved to be the worst combination in terms of maximizing subsequent lactation milk yield.
\end{abstract}

days dry / lactational milk yield

Résumé - Période de tarissement minimale pour maximiser la production laitière pendant la lactation suivante. L'objectif de cette recherche a été de déterminer les effets de la durée de la période de tarissement (PT) sur la production totale de lait pendant la lactation suivant le tarissement, et d'identifier la période minimale nécessaire pour maximiser cette production. Les données utilisées dans cette étude ont été collectées auprès d'associations d'éleveurs laitiers d'Amérique du Nord entre janvier 1997 et décembre 2003, et extraites de la base nationale de l'Animal Improvement Programs Laboratory. La production laitière totale, calculée à partir des productions mensuelles, a été utilisée dans cette étude. Le modèle d'analyse contenait les effets du troupeau-année de vêlage, de l'âge au vêlage, et de la durée de la PT. Des interactions furent ajoutées au modèle pour déterminer si les effets de la PT sur la production après tarissement dépendaient de la production avant tarissement, de l'âge au vêlage, du score de cellules somatiques et de l'intervalle vêlage-insémination fécondante. La production de lait après tarissement a généralement été maximale pour une PT de 60 à 65 jours,

* Corresponding author: mkuhn@aipl.arsusda.gov 
quelle que soit la parité. Les effets de la durée de la PT sur la production laitière ont généralement été constants quelle que soit la parité, mais de courtes PT après la première lactation ont été plus néfastes à la production laitière que de courtes PT après les lactations de parités supérieures. Des PT inférieures à 20 jours entraînaient des pertes de lait importantes à la lactation suivante. Une PT courte chez des vaches hautes productrices et fécondées rapidement après le vêlage est la pire combinaison pour maximiser la production à la lactation suivante.

\section{jours de tarissement / production laitière totale}

\section{INTRODUCTION}

Although dairy farmers have long sought the most efficient means possible to produce high quality milk, the necessity of this efficiency has increased over time, at least in the United States (U.S.), because of farm milk prices that have fell well short of matching the rate of inflation [13]. Costs of production have risen dramatically while farm milk price has remained basically flat [13]. Thus, the search for management and breeding practices to maximize efficiency and income on investment are more important now than ever before to the dairy producer.

One option for improved income on investment might be to shorten dry period length. Average days dry (DD) for U.S. Holsteins is about $60 \mathrm{~d}$ [15]. By shortening the dry period from 60 to $30 \mathrm{~d}$, for example, the farmer's investment, the cow, would generate income for an additional $30 \mathrm{~d}$ per lactation. When multiplied by an average of 2.5 lactations, this would be an additional $75 \mathrm{~d}$ of production over the lifetime of a cow. If a cow maintained a $20 \mathrm{~kg}$ average during the 75 extra days in milk (DIM), an additional $1500 \mathrm{~kg}$ of lifetime milk would be produced. The question, however, is what effect would a shortened dry period have on the cow. Does it decrease production in the subsequent lactation? Does it cause additional health or fertility problems in the subsequent lactation? Does it do any harm to the calf being carried by the cow? Does it reduce herd life? If one or more of these negative consequences were true, the costs associated with a shortened dry period could easily outweigh the benefits.
Considerable research has been done regarding the effect of DD on subsequent lactation milk yield. Grummer and Rastani [10] provided a recent review of DD including a review of literature to date. Past studies have concluded, for the most part, that a $60 \mathrm{~d}$ dry period maximizes milk yield in the subsequent lactation. However, most published research to date has focused primarily on $305 \mathrm{~d}$, twice daily milking, mature equivalent (ME) milk yield (ME = standardization for age at calving), rather than actual milk yield. Furthermore, with the exception of several recent designed trials, much of the research done to date is now 20 years old or older and certainly cows have changed genetically over that time period. Mean breeding value for lactational milk yield in U.S. Holsteins, for example, has increased $2050 \mathrm{~kg}$ since 1982 [1]. Higher potential for milk yield may mean that cows are able to sustain production for a longer period of time, which might make shorter dry periods more practical. Management practices have changed over the last 20 years as well. The combination of management and genetics resulting in higher phenotypic levels of production, however, might also result in a demand for longer rest periods between lactations in order to sustain production, health, and fertility in subsequent lactations. It is simply unknown what effect variation in DD has on modern dairy cows and reevaluation is warranted.

The primary objective of this research was to utilize data from modern day dairy cattle to determine the effect of DD on actual milk yield and to identify the minimum dry period length needed to maximize milk yield in the subsequent lactation. A further objective was to determine if the 
effect of DD on milk yield depended on parity, level of production, age at calving, somatic cell score ( $\mathrm{SCS}=\log _{2}$ ( (somatic cell count/100 000) +3 , where somatic cell count is the number of somatic cells per milliliter of milk), or days open (DO) in the previous lactation. Since most research has been done using $305 \mathrm{~d}$ ME records, another objective was to determine the propriety of using actual records for investigation of DD effects.

\section{MATERIALS AND METHODS}

\subsection{Data}

Field data collected on U.S. Holsteins through the dairy herd improvement association (DHI), and extracted from the Animal Improvement Programs Laboratory national database, were used for analysis. Actual lactation records were used in this study. The only standardization done was to a twice daily milking basis. Records less than $305 \mathrm{~d}$ were not extended to $305 \mathrm{~d}$ and all production beyond $305 \mathrm{~d}$ was included. The only restriction put on length of lactation was that lactations more than 2 years long were deleted. For comparison, DD effects using ME records were estimated as well. Actual yields were used instead of 305 d or 305 d ME yields for 2 reasons. First, farmers are paid for actual production, not extended or ME production. Secondly, use of extended records could conceal the exact variation that needs to be discovered. If a short dry period, for example, caused problems in the subsequent lactation that resulted in early culling or earlier dry off, then extending records to a $305 \mathrm{~d}$ basis would tend to reduce or eliminate that effect. If short subsequent lactations are unrelated to DD, then they will occur randomly across dry periods and cause no bias in the analyses. Thus, actual milk yield was used in this study and was calculated from test-day yields using the test-interval method [21] and the adjustment factors of Shook et al. [23].
Only data on Holstein cows first calving on or after January 1, 1997 were included because complete lactation information was not kept prior to 1997. Records were also required to be initiated no later than December 31, 2002. Herds were required to be on test for the entire time period from January, 1997 to December, 2003. Herds needed to be on test through 2003 in order to ensure nearly complete information for cows that initiated their records in late 2002. Each herd was also required to have a minimum of 5 cows in each year; if a herd had fewer than 5 cows in any particular year, the herd was entirely deleted. Finally, in regard to herd edits, the date at which complete lactation information was available varied somewhat across dairy records processing centers because not all centers began sending complete lactation information at the same time. Thus, the January 1997 lower limit for date of inclusion had to be moved forward for some herds. This change in edit affected western herds the most.

Records initiated by abortion were excluded as well as cows known to be embryo transfer donors because these factors could lead to dry periods or lactations of abnormal length. Dry periods were required to be between 0 and $120 \mathrm{~d}$ in length. Records where DD was more than $120 \mathrm{~d}$ were deleted. Another important edit was that the expected calving date, based on last reported DO, and the actual calving date had to agree within $10 \mathrm{~d}$. Some researchers [4, 10] have argued that analyses using DHI data are "biased" because the short dry periods included are primarily those that are unplanned and if the cow had a known calving date, she would have been managed differently for the short DD. This edit ensured that the farmer knew when the cow was going to calve because, in effect, the producer reported it to DHI.

Days dry categories were formed for analysis. The 16 categories are defined in Table I along with number of records in each category, after edits and by parity. A 
Table I. Days dry categories and corresponding dry period lengths with sample sizes for each parity.

\begin{tabular}{rrrrr}
\hline $\begin{array}{c}\text { Days dry } \\
\text { category }\end{array}$ & Days dry & Parity 2 & Number of records \\
\cline { 3 - 5 } & $0-10$ & 1708 & 456 & Parity 4 \\
\hline 1 & $11-20$ & 1283 & 296 & 164 \\
3 & $21-30$ & 3785 & 989 & 90 \\
4 & $31-35$ & 4629 & 1330 & 369 \\
5 & $36-40$ & 9249 & 3076 & 433 \\
6 & $41-45$ & 19312 & 6710 & 1049 \\
7 & $46-50$ & 38268 & 13800 & 2292 \\
8 & $51-55$ & 64473 & 24214 & 4689 \\
9 & $56-60$ & 76176 & 29806 & 8053 \\
10 & $61-65$ & 56835 & 23838 & 10214 \\
11 & $66-70$ & 27833 & 13002 & 8254 \\
12 & $71-80$ & 18082 & 10662 & 4701 \\
13 & $81-90$ & 7859 & 6118 & 4109 \\
14 & $91-100$ & 4956 & 4250 & 2445 \\
15 & $101-110$ & 3288 & 3004 & 1640 \\
16 & $111-120$ & 2432 & 2071 & 1047 \\
\hline Total & & 340168 & 143622 & 742 \\
\hline
\end{tabular}

total of 340168 second lactation records, from 3627 herds, were used for analysis.

\subsection{Model for analysis}

The three-step approach of Kuhn and Hutchison [14]: (1) estimation of cow effects from an animal model, (2) prior correction of records for cow effects, and (3) estimation of DD effects from a model that included previous lactation milk yield (PrevM), was used for analysis. Dry period length is correlated with previous lactation milk yield $[15,22]$. It has been shown, however, that the above approach estimates DD effects without bias by cow effects, in spite of that correlation [14].

The linear, fixed effects model used for analysis was:

$\mathrm{y}^{*}=\mathrm{HY}+\mathrm{YR}-\mathrm{ST}-\mathrm{MO}+\beta_{1} \times$ PrevM

$+\beta_{2} \times$ Age $+\beta_{3} \times$ Age $^{2}+$ DD $+e$ where $y^{*}$ is actual milk yield corrected for cow effects, HY is herd-year of calving, YR-ST-MO is year-state-month of calving, Age is age at calving, and DD was a categorical variable for dry period length, defined in Table I. Herd-year was used, instead of HY-season, to avoid small group sizes. Month was added to the model to account for season effects. Month effects were allowed to differ by state as well as year within state, hence YR-ST-MO. Previous as well as current DO were included in preliminary analyses but had little effect on overall results and, therefore, were not included in the final model. Separate analyses were done for parities 2 through 4 to determine if results differed by lactation.

For estimation of cow effects, additive genetic and permanent environmental (PE) effects were added to equation (1) and PrevM was dropped from the model. A three-trait model that included fat and protein 
Table II. Subclass sizes by days dry and previous lactation milk yield categories, used for interaction analysis.

\begin{tabular}{crrrrr}
\hline \multirow{2}{*}{$\begin{array}{c}\text { Days dry } \\
\text { category }\end{array}$} & Days dry & \multicolumn{1}{c}{ Previous milk yield category } \\
\cline { 3 - 6 } & $0-10$ & 332 & \multicolumn{1}{c}{3} & \multicolumn{1}{c}{3} \\
\hline 1 & $11-25$ & 661 & 400 & 474 & 502 \\
3 & $26-40$ & 3755 & 635 & 662 & 687 \\
4 & $41-50$ & 13303 & 14733 & 4313 & 4137 \\
5 & $51-60$ & 33731 & 36605 & 36062 & 34251 \\
6 & $61-70$ & 21634 & 21301 & 21144 & 20589 \\
7 & $71-80$ & 5454 & 4052 & 3821 & 4755 \\
8 & $81-90$ & 2549 & 1490 & 1524 & 2296 \\
9 & $91-120$ & 3616 & 1734 & 1926 & 3400 \\
\hline
\end{tabular}

yields in addition to milk yield was used, in contrast to a single trait model, in order to increase accuracy of breeding value and PE estimates. Cows were required to have a first lactation, for estimation of cow effects, but were not required to have a second or later lactation. Following the approach of Kuhn and Hutchison [14], lactation 1 records were given their own unique DD category.

\subsection{Interactions}

To determine if the effects of DD on subsequent lactation milk yield depended on previous lactation milk yield, age at calving, SCS, or DO, the main effect of the previous lactation variable, fit as a categorical variable, and its interaction with the DD categorical variable were added to model 1 . Prior adjustment for cow effects was also done for the interaction analyses. For interaction with PrevM, the covariate of PrevM was dropped from the model.

Examination of interactions generates a large volume of results and also requires further subdivision of the data. Two things were done to limit the amount of output and to limit reduction in subclass sizes. First, DD categories were redefined for the interaction analyses resulting in 9 rather than 16 categories, defined in Table II. Secondly, the interactions were investigated for second lactation milk yield only. If interac- tions exist, it is likely they would be revealed through analysis of the second lactation data set.

Four categories, based on quartiles, were used for PrevM, previous DO, and previous SCS. The 3 categories used for age at calving in first lactation were (1) less than 2 years, (2) between 2 and 2.5 years, and (3) greater than 2.5 years. Days dry categories used for the interaction analyses are given in Table II along with subclass sample sizes for the PrevM analysis. Means as well as upper and lower limits for the PrevM, previous DO, and previous SCS categories are listed in Table III.

The three-way interaction between DD, PrevM, and previous DO was also examined. The model included herd-year, yearstate-month, the linear and quadratic effects of age at calving, the main effects of DD, PrevM, and previous DO, the two-way interactions of DD with PrevM and previous DO, and the three-way interaction between DD, PrevM, and previous DO. The same 9 DD categories used for the two-way interactions were used to study the threeway interaction. However, to make investigation of the three-way interaction more manageable and to keep subclass sizes as large as possible, only 3 categories, based on percentiles, were used for PrevM and previous DO. 
Table III. Mean, minimum, and maximum, by quartiles, for previous (first lactation) milk yield, previous days open (DO), and previous somatic cell score (SCS) categories used in the interaction analyses.

\begin{tabular}{|c|c|c|c|c|c|c|c|c|c|}
\hline \multirow[b]{2}{*}{ Quartiles } & \multicolumn{3}{|c|}{ Mean } & \multicolumn{3}{|c|}{ Minimum } & \multicolumn{3}{|c|}{ Maximum } \\
\hline & Milk (kg) & DO & SCS & Milk (kg) & DO & SCS & Milk (kg) & $\mathrm{DO}$ & SCS \\
\hline 1 & 7170 & 62 & 1.08 & 489 & 30 & 0.10 & 8294 & 76 & 1.49 \\
\hline 2 & 9019 & 92 & 1.84 & 8295 & 77 & 1.50 & 9731 & 110 & 2.21 \\
\hline 3 & 10568 & 136 & 2.68 & 9732 & 111 & 2.22 & 11569 & 168 & 3.22 \\
\hline 4 & 13902 & 234 & 4.32 & 11570 & 169 & 3.23 & 30859 & 300 & 9.70 \\
\hline
\end{tabular}

\subsection{Expression of results: estimable functions calculated}

Least-squares means for the DD subclasses were not estimable with the model used for analysis in this study. Differences between subclasses, however, were estimable. Main effects of DD were expressed relative to category 10 (61 to $65 \mathrm{DD})$, i.e., as category $i$ minus category 10 , for $i=1$ to 16 , since the current U.S. mean dry period is $60 \mathrm{~d}$ [15]. Interactions were expressed relative to category 6 (61 to $70 \mathrm{DD})$. Mean levels of production (arithmetic means) for cows with 61 to 65 DD were $11357 \mathrm{~kg}$, $11538 \mathrm{~kg}$, and $11377 \mathrm{~kg}$ for lactations 2 through 4 , respectively.

\section{RESULTS AND DISCUSSION}

\subsection{Main effects}

Main effect results for milk yield are in Table IV. As an example of interpretation, the $-2442 \mathrm{~kg}$ for DD category 1 in second lactation means that cows with 0 to $10 \mathrm{DD}$ produce $2442 \mathrm{~kg}$ less milk than cows given a 61 to $65 \mathrm{~d}$ dry period. Milk yield in the subsequent lactation was generally maximized with a 61 to $65 \mathrm{~d}$ dry period, regardless of parity. Days dry effects on milk yield were, for the most part, consistent across lactations, although dry periods less than $30 \mathrm{~d}$ may be somewhat more detrimental to second lactation milk yield than for later lactations.
All dry periods less than $61 \mathrm{~d}$ resulted in lost production in the following lactation but dry periods of less than $20 \mathrm{~d}$ were severely, and by far the most, detrimental. Cows with 10 or fewer DD produced 2442 $\mathrm{kg}$ less milk yield in second lactation than cows with 61 to 65 DD. For lactation 2, moving from a dry period of $10 \mathrm{~d}$ or less to a dry period between 11 and 20 d increased production only $148 \mathrm{~kg}$, whereas moving to 21 to 30 DD increased milk yield an additional $843 \mathrm{~kg}$. Thereafter, milk yield increased, with increasing DD, at a decreasing rate. Moving from category 3 to 4 , for example, increased production by $433 \mathrm{~kg}$ but increasing DD from category 4 to 5 added only $242 \mathrm{~kg}$ of lactational yield in second lactation.

Thus, the increase in milk yield is not linear over the range of 0 to 60 DD. Funk et al. [9] and Schaeffer and Henderson [22] also found non-linear increases in yield with increasing DD over this range of dry periods. There also appears to be somewhat of a threshold dry period length where cows with at least (roughly) 20 DD experience considerably less milk yield loss in the subsequent lactation than cows that had fewer than 20 DD. Funk et al. [9] found a similar result, although this "jump" at 20 DD was less pronounced in their results than what was found in this study, perhaps because of their use of ME records. The reason for the non-linear increase in subsequent lactation yield, with increasing DD, appears to be unknown. It would seem, however, that it must be related to the rate at which factors 
Table IV. Main effect results for milk yield, by days dry (DD) category.

\begin{tabular}{ccccc}
\hline \multirow{2}{*}{$\begin{array}{c}\text { Days dry } \\
\text { category }\end{array}$} & & \multicolumn{3}{c}{ Milk $^{1}(\mathrm{~kg})$} \\
\cline { 2 - 5 } & Days dry & Parity 2 & Parity 3 & Parity 4 \\
\hline 1 & $0-10$ & $-2442 \pm 62.8$ & $-2262 \pm 134.9$ & $-2270 \pm 267.4$ \\
2 & $11-20$ & $-2294 \pm 72.5$ & $-2026 \pm 168.0$ & $-1989 \pm 376.8$ \\
3 & $21-30$ & $-1451 \pm 44.1$ & $-1402 \pm 93.6$ & $-1067 \pm 179.0$ \\
4 & $31-35$ & $-1018 \pm 39.6$ & $-906 \pm 80.7$ & $-613 \pm 164.1$ \\
5 & $36-40$ & $-776 \pm 29.3$ & $-728 \pm 55.1$ & $-691 \pm 108.1$ \\
6 & $41-45$ & $-538 \pm 21.9$ & $-498 \pm 39.7$ & $-439 \pm 77.8$ \\
7 & $46-50$ & $-345 \pm 17.1$ & $-366 \pm 30.5$ & $-428 \pm 59.1$ \\
8 & $51-55$ & $-233 \pm 14.5$ & $-210 \pm 25.3$ & $-163 \pm 49.5$ \\
9 & $56-60$ & $-86 \pm 13.6$ & $-82 \pm 23.6$ & $-33 \pm 45.7$ \\
10 & $61-65$ & 0 & 0 & 0 \\
11 & $66-70$ & $14 \pm 17.9$ & $-99 \pm 29.6$ & $34 \pm 56.2$ \\
12 & $71-80$ & $-189 \pm 21.3$ & $-201 \pm 32.1$ & $-171 \pm 60.0$ \\
13 & $81-90$ & $-306 \pm 30.2$ & $-267 \pm 39.7$ & $-135 \pm 73.1$ \\
14 & $91-100$ & $-416 \pm 37.1$ & $-284 \pm 46.2$ & $-212 \pm 85.4$ \\
15 & $101-110$ & $-300 \pm 44.7$ & $-229 \pm 53.7$ & $-73 \pm 103.4$ \\
16 & $111-120$ & $-333 \pm 51.6$ & $-141 \pm 63.3$ & $-366 \pm 121.0$ \\
\hline
\end{tabular}

${ }^{1}$ Difference in milk yield: days dry category $i$ minus days dry category $10 \pm$ SE of difference, where $i=1$ to 16 .

underlying the effect of dry period operate. Perhaps mammary recuperation, for example, occurs more rapidly immediately after dry off than later in the dry period or maybe body condition is replaced quicker shortly after dry off than later in the dry period. The threshold of approximately 20 DD may be a point where the rate of one or more recuperative factors begins to decline. Since actual records were used in this study, these "recuperative factors" may not all be directly related to milk yield. If increased health problems, for example, were associated with shorter dry periods, this could also lead to lower means in actual yield for the shortened dry periods, especially if such problems led to culling.

Although 61 to $65 \mathrm{~d}$ maximized production in the subsequent lactation, losses with dry periods of at least $45 \mathrm{~d}$ were fairly minor and might be easily offset by the milk yield gained in the previous lactation. Cows with
46 to $50 \mathrm{DD}$, for example, produced only $345 \mathrm{~kg}$ less milk than cows with dry periods of 61 to $65 \mathrm{~d}$. Considering a $60 \mathrm{~d}$ vs. $45 \mathrm{~d}$ dry period, if a cow averaged $23 \mathrm{~kg}$ during the last $15 \mathrm{~d}$ of lactation, the additional $345 \mathrm{~kg}$ of milk from first lactation would offset the loss in the subsequent lactation. Thus, while these results clearly show milk yield loss in subsequent lactation for dry periods less than $60 \mathrm{~d}$, dry periods shorter than $60 \mathrm{~d}$ may still be useful.

\subsection{Interactions}

Whether or not the effect of DD depends on PrevM, age at calving, previous SCS, or previous DO can be seen by comparing across columns, for a given factor, in Tables V and VI. Differences across columns, and especially a consistent pattern across columns, would be indicative of interaction. Interaction effects for second 
Table V. Interactions of DD with previous lactation milk yield and age at first calving.

\begin{tabular}{|c|c|c|c|c|c|c|c|c|}
\hline \multirow{2}{*}{$\begin{array}{l}\text { Days dry } \\
\text { category }\end{array}$} & \multirow[b]{2}{*}{ Days dry } & \multicolumn{4}{|c|}{ Previous milk yield category $^{1}(\mathrm{~kg})$} & \multicolumn{3}{|c|}{ Age at calving category ${ }^{1}(\mathrm{~kg})$} \\
\hline & & 1 & 2 & 3 & 4 & 1 & 2 & 3 \\
\hline 1 & $0-10$ & -1817 & -2668 & -2696 & -2332 & -2830 & -2448 & -2126 \\
\hline 2 & $11-25$ & -1751 & -1806 & -2204 & -1816 & -2218 & -1998 & -1787 \\
\hline 3 & $26-40$ & -890 & -1043 & -904 & -772 & -1042 & -950 & -936 \\
\hline 4 & $41-50$ & -402 & -438 & -419 & -326 & -474 & -424 & -443 \\
\hline 5 & $51-60$ & -152 & -177 & -188 & -104 & -180 & -178 & -152 \\
\hline 6 & $61-70$ & 0 & 0 & 0 & 0 & 0 & 0 & 0 \\
\hline 7 & $71-80$ & -215 & -185 & -198 & -149 & -214 & -98 & -42 \\
\hline 8 & $81-90$ & -277 & -192 & -440 & -357 & -321 & -119 & -207 \\
\hline 9 & $91-120$ & -297 & -495 & -472 & -390 & -344 & -147 & -34 \\
\hline
\end{tabular}

${ }^{1}$ Difference in milk yield: days dry category $i$ minus days dry category 6, where $i=1$ to 9 . Previous milk yield categories were based on percentiles. Age at calving categories were define as, 1 : less than 2 years, 2: between 2 and 2.5 years, and 3: greater than 2.5 years.

Table VI. Interaction of days dry with previous (first) lactation SCS and days open.

\begin{tabular}{|c|c|c|c|c|c|c|c|c|c|}
\hline \multirow{2}{*}{$\begin{array}{l}\text { Days dry } \\
\text { category }\end{array}$} & \multicolumn{5}{|c|}{ Previous SCS $^{1}(\mathrm{~kg})$} & \multicolumn{4}{|c|}{ Previous days open $^{1}(\mathrm{~kg})$} \\
\hline & Days dry & 1 & 2 & 3 & 4 & 1 & 2 & 3 & 4 \\
\hline 1 & $0-10$ & -2579 & -2676 & -2242 & -2342 & -2539 & -2325 & -2784 & -2025 \\
\hline 2 & $11-25$ & -2186 & -1801 & -1927 & -1882 & -2119 & -1895 & -2036 & -1717 \\
\hline 3 & $26-40$ & -968 & -984 & -881 & -847 & -1161 & -1101 & -880 & -751 \\
\hline 4 & $41-50$ & -415 & -406 & -391 & -390 & -515 & -498 & -465 & -354 \\
\hline 5 & $51-60$ & -191 & -158 & -133 & -134 & -217 & -196 & -162 & -133 \\
\hline 6 & $61-70$ & 0 & 0 & 0 & 0 & 0 & 0 & 0 & 0 \\
\hline 7 & $71-80$ & -154 & -205 & -185 & -195 & -167 & -75 & -114 & -13 \\
\hline 8 & $81-90$ & -318 & -233 & -356 & -254 & -110 & -165 & -170 & -16 \\
\hline 9 & $91-120$ & -396 & -260 & -361 & -362 & -187 & -188 & -148 & -58 \\
\hline
\end{tabular}

${ }^{1}$ Difference in milk yield: days dry category $i$ minus days dry category 6 , where $i=1$ to 9 .

Previous SCS and days open categories were based on percentiles.

lactation milk yield were generally minor. The dry period to maximize second lactation production did not depend on PrevM, age at calving, SCS, or DO in the previous lactation.

Although most interactions were minor, they were not non-existent. For PrevM in Table V, comparing categories 2, 3, and 4 to category 1 indicates that higher production cows pay a larger price for dry periods less than $60 \mathrm{~d}$ than lower production cows. The results for age at calving clearly show that dry periods less than $40 \mathrm{~d}$ have a more negative impact on primiparous cows that calved at a younger age, due, presumably, to differences in physiological maturity. Cows with lower SCS (categories 1 and 2, Tab. VI) benefit more from dry periods of at least $40 \mathrm{~d}$ than cows with higher SCS. Perhaps cows with higher SCS experience damage to their mammary tissue, caused by mastitis, which makes them more indifferent to the production benefits of a longer dry period.

The two-way interaction between DD and previous DO is illustrated in Table VI. 
Table VII. Subclass sample sizes and estimates for the three-way interaction of days dry, previous milk yield (PrevM), and previous (first lactation) days open (DO).

\begin{tabular}{|c|c|c|c|c|c|c|c|c|c|c|}
\hline \multirow{3}{*}{$\begin{array}{c}\text { Days } \\
\text { dry } \\
\text { category }\end{array}$} & \multirow{3}{*}{$\begin{array}{c}\text { Days } \\
\text { dry }\end{array}$} & \multicolumn{9}{|c|}{ Subclass Sample Sizes } \\
\hline & & \multicolumn{3}{|c|}{ PrevM1 $^{1}$} & \multicolumn{3}{|c|}{ PrevM21 } & \multicolumn{3}{|c|}{ PrevM31 } \\
\hline & & $\mathrm{DO}^{2}$ & $\overline{\mathrm{DO}} 2^{2}$ & $\overline{\mathrm{DO}^{2}}$ & DO1 & DO2 & DO3 & DO1 & DO2 & DO3 \\
\hline 1 & $0-10$ & 326 & 102 & 26 & 304 & 214 & 74 & 119 & 217 & 326 \\
\hline 2 & $11-25$ & 628 & 194 & 40 & 410 & 328 & 126 & 129 & 287 & 503 \\
\hline 3 & $26-40$ & 3346 & 1451 & 287 & 2340 & 2364 & 883 & 584 & 1773 & 3273 \\
\hline 4 & $41-50$ & 11715 & 5485 & 976 & 7553 & 9003 & 3367 & 1343 & 5661 & 12477 \\
\hline 5 & $51-60$ & 29192 & 14195 & 2488 & 17209 & 22665 & 8731 & 2580 & 12445 & 31144 \\
\hline 6 & $61-70$ & 17486 & 9401 & 1878 & 8891 & 13244 & 6270 & 1140 & 6510 & 19848 \\
\hline 7 & $71-80$ & 3331 & 2576 & 954 & 900 & 2075 & 2136 & 95 & 726 & 5289 \\
\hline 8 & $81-90$ & 1137 & 1243 & 698 & 123 & 561 & 1282 & 6 & 104 & 2705 \\
\hline 9 & $91-120$ & 1147 & 1577 & 1505 & 37 & 329 & 1971 & 3 & 48 & 4059 \\
\hline \multirow{3}{*}{$\begin{array}{c}\text { Days } \\
\text { dry } \\
\text { category }\end{array}$} & \multirow{3}{*}{$\begin{array}{c}\text { Days } \\
\text { dry }\end{array}$} & \multicolumn{9}{|c|}{ Estimates $^{3}$} \\
\hline & & \multicolumn{3}{|c|}{ PrevM1 (kg) } & \multicolumn{3}{|c|}{ PrevM2 (kg) } & \multicolumn{3}{|c|}{ PrevM3 (kg) } \\
\hline & & DO1 & $\mathrm{DO} 2$ & DO3 & DO1 & $\mathrm{DO} 2$ & DO3 & DO1 & $\mathrm{DO} 2$ & DO3 \\
\hline 1 & $0-10$ & -2205 & -2140 & -1158 & -2953 & -2620 & -1968 & -2671 & -2862 & -2388 \\
\hline 2 & $11-25$ & -1917 & -1561 & -1942 & -2252 & -2095 & -1561 & -2891 & -2115 & -1753 \\
\hline 3 & $26-40$ & -1049 & -742 & -501 & -1188 & -1033 & -545 & -1456 & -1105 & -764 \\
\hline 4 & $41-50$ & -440 & -376 & -235 & -533 & -473 & -354 & -589 & -517 & -321 \\
\hline 5 & $51-60$ & -159 & -140 & -129 & -238 & -207 & -145 & -298 & -217 & -107 \\
\hline 6 & $61-70$ & 0 & 0 & 0 & 0 & 0 & 0 & 0 & 0 & 0 \\
\hline 7 & $71-80$ & -192 & -221 & -159 & -104 & -69 & -118 & 401 & -48 & -127 \\
\hline 8 & $81-90$ & -356 & -149 & -63 & -21 & -233 & -122 & -1540 & -212 & -291 \\
\hline 9 & $91-120$ & -429 & -352 & -66 & 208 & -57 & -218 & -5680 & -676 & -348 \\
\hline
\end{tabular}

${ }^{1}$ PrevM $i=$ previous milk yield, where $i=$ category 1 through 3 , based on percentiles;

${ }^{2} \mathrm{DO} i=$ previous days open, where $i=$ category 1 through 3 , based on percentile;

${ }^{3}$ Difference in milk yield: days dry category $i$ minus days dry category 6 , where $i=1$ to 9 .

Comparing the first 3 categories of previous DO to category 4 indicates that cows with long DO are less affected by dry periods of less than $60 \mathrm{~d}$ than cows with shorter DO. Table VII shows the three-way interaction between DD, PrevM, and previous DO and also contains subclass sample sizes. A few estimates in Table VII do not seem to fit the general pattern or appear rather extreme, but these are subclasses with small numbers. The general result illustrated in Table VII is that the negative impact of shortened dry periods is larger for cows with short DO than for cows with longer DO and that is even more pronounced for higher production cows than for lower production cows. In terms of maximizing subsequent lactation milk yield, the worst combination, at least in first lactation, is a short dry period for high production cows that conceived early in lactation.

\subsection{Comparison of alternative methods}

Actual milk yields, not extended to $305 \mathrm{~d}$, were used in this research mainly because standardization to a $305 \mathrm{~d}$ or $305 \mathrm{~d}$ ME basis could have nullified variation due to DD. 
Table VIII. Comparison of methods using parity $2^{1}$.

\begin{tabular}{crrrr}
\hline \multirow{2}{*}{$\begin{array}{c}\text { Days dry } \\
\text { category }\end{array}$} & \multicolumn{3}{c}{ Days dry } & \multicolumn{2}{c}{ Actual Milk $(\mathrm{kg})^{2}$} & $\mathrm{ME}^{2}(\mathrm{~kg})$ \\
\cline { 3 - 4 } \cline { 5 - 5 } $\mathrm{I}^{3}$ & \multicolumn{1}{c}{$\mathrm{II}^{4}$} & \multicolumn{1}{c}{$\mathrm{III}^{5}$} \\
\hline 1 & $0-10-2442$ & -1761 & -1140 \\
2 & $11-20-2$ & 294 & -1668 & -1128 \\
3 & $21-30-1451$ & -1121 & -752 \\
4 & $31-35-1$ & 018 & -763 & -494 \\
5 & $36-40$ & -776 & -618 & -380 \\
6 & $41-45$ & -538 & -443 & -277 \\
7 & $46-50$ & -345 & -308 & -187 \\
8 & $51-55$ & -233 & -185 & -113 \\
9 & $56-60$ & -86 & -73 & -39 \\
10 & $61-65$ & 0 & 0 & 0 \\
11 & $66-70$ & 14 & 12 & 7 \\
12 & $71-80$ & -189 & -90 & -62 \\
13 & $81-90$ & -306 & -131 & -96 \\
14 & $91-100$ & -416 & -152 & -126 \\
15 & $101-110$ & -300 & -84 & -90 \\
16 & $111-120$ & -333 & -76 & -86 \\
\hline
\end{tabular}

${ }^{1}$ All analyses were on records with a prior correction for cow effects and with previous lactation yield in the model.

${ }^{2}$ Difference in milk yield: days dry category $i$ minus days dry category 10 , where $i=1$ to 16 .

${ }^{3}$ I: From model [1].

${ }^{4}$ II: Model [1], plus days in milk (DIM) included as a covariate.

${ }^{5}$ III: Model [1] using mature-equivalent milk yield.

Comparison of columns I and III in Table VIII illustrates the difference between using actual and ME records for milk yield. Use of $\mathrm{ME}$ records grossly underestimates DD effects, especially the negative impact of dry periods less than $50 \mathrm{~d}$. The difference between actual and ME in DD category 1, for example, was about $1300 \mathrm{~kg}$. Actual records do reveal variation related to DD that is obscured by the use of ME records. Nearly all DD research for lactational milk yield, published to date, has been based on $305 \mathrm{~d}$ or $305 \mathrm{~d}$ ME records. These results show, however, that use of actual yields is more appropriate and more informative than ME yields, for investigation of DD effects on production. Similar results for lactations 3 and 4 are given in the appendix.

Column II in Table VIII presents results for actual, second lactation milk yield when DIM is included in the model. Standardization for lactation length generally accounted for about half of the difference between results for $\mathrm{ME}$ and actual yields in second lactation. This also implies that part of the DD effect on actual yield is related to DIM which prompted further study of the relationship between DIM and DD.

\subsection{Relationship of DIM and DD}

Days in milk in second lactation was fit using model [1] and differences between DD groups, for DD between first and second parities, are presented in Table IX. Cows with extreme dry periods, either short or long, have fewer DIM in the subsequent lactation. Cows with 20 or fewer DD

Table IX. Relationship between days dry and subsequent days in milk (DIM) for parity 2 .

\begin{tabular}{crr}
\hline Days dry category & Days dry & DIM $^{1}$ \\
\hline 1 & $0-10$ & -23 \\
2 & $11-20$ & -22 \\
3 & $21-30$ & -9 \\
4 & $31-35$ & -6 \\
5 & $36-40$ & -3 \\
6 & $41-45$ & -1 \\
7 & $46-50$ & 1 \\
8 & $51-55$ & -1 \\
9 & $56-60$ & 0 \\
10 & $61-65$ & 0 \\
11 & $66-70$ & -1 \\
12 & $71-80$ & -7 \\
13 & $81-90$ & -12 \\
14 & $91-100$ & -17 \\
15 & $101-110$ & -16 \\
16 & $111-120$ & -19
\end{tabular}

${ }^{1}$ Difference in DIM: days dry category $i$ minus days dry category 10 , where $i=1$ to 16 . 
averaged about 23 fewer DIM in the subsequent lactation than cows with dry periods between 41 and $70 \mathrm{~d}$. Cows with 111 to 120 DD averaged 19 fewer DIM, relative to cows with 61 to 65 DD. Part of this difference in DIM may due to more intense culling on cows in the extremes for dry period length. Fifty-seven percent of the cows with DD between 21 and $80 \mathrm{~d}$ were culled after second lactation whereas culling rates after second lactation for cows with DD between 0 and $20 \mathrm{~d}$ was $63 \%$ and was $65 \%$ for cows with DD between 81 and $120 \mathrm{~d}$.

It is important to note that differences in DIM do not nearly account for the entire effect of DD on milk yield. As indicated in column II of Table VIII, even after adjusting for DIM, cows with less than 10 DD still averaged $1761 \mathrm{~kg}$ less milk in subsequent lactation than cows with 61 to 65 DD. Nonetheless, cows with short dry periods do have fewer DIM in the subsequent lactation and this appears to be due in part to more intense culling on those cows in second lactation. Lower production, caused by the shorter dry period, may largely account for the shorter lactation lengths and more intense culling for the short dry period cows.

\subsection{Long dry periods}

The general result of a reduced rest period (shorter DD) leading to lower production is perhaps intuitively expected. Furthermore, biological bases for this result have been established. Capuco et al. [5], for example, found that "a dry period is important for replacing senescent mammary epithelial cells and increasing the epithelial component of the gland prior to the next lactation". However, cows with excessively long dry periods also had slightly lower production in the subsequent lactation. Cows with dry periods longer than $80 \mathrm{~d}$ had about $200 \mathrm{~kg}$ less yield, at least in second lactation (Tab. IV), compared to cows with 61 to 65 DD. Although the effect of long DD on milk yield was rather small and considerably less than the effect of shortened dry periods, this result was not expected. It would seem that after the minimum dry period to maximize subsequent lactation milk yield was met, any additional DD would just result in the same production as 60 DD. Lower yield associated with dry periods longer than $60 \mathrm{~d}$ was not due to poorer cows receiving longer dry periods more often than higher producing cows because cow effects were corrected for in this study. Research has clearly shown that, with the methodology used in this study, all dry period categories are estimated without bias from cow effects, even when poorer cows receive longer dry periods [14].

Days in milk accounted for a large portion of the lower production following long dry periods (Tab. VIII, column II). However, that does not explain why, biologically, longer dry periods lead to reduced milk yield. The question remains as to why cows with dry periods of roughly $80 \mathrm{~d}$ or more would have fewer DIM, compared to cows with 60 DD. Higher body condition score (BCS) has been associated with lower lactational milk yield [7, 25]. Perhaps cows with long dry periods put on excess weight which may, in turn, lead to lower production in the subsequent lactation. Body condition scores were obtained from Dairy Records Management Systems to test this hypothesis. Unfortunately, only 3145 of the second lactations included in this study had a BCS at calving. Given the small sample size, the model for analysis was simplified to include only herd, month of calving, age at calving, PrevM fit as a covariate, and BCS and DD, both fit as categorical variables. Only 3 DD categories were used for this analysis: 0 to $45 \mathrm{~d}, 46$ to $70 \mathrm{~d}$, and 71 to $120 \mathrm{~d}$. Since the cows used for this analysis comprised only a small subset of the total data set, the same analysis was done, for comparison, using just these cows but without BCS in the model. The results indicated that BCS did not account for the lower production of cows with long DD. The difference between DD categories 2 and 3 was about $290 \mathrm{~kg}$ (similar to Tab. IV) both with and without $\mathrm{BCS}$ in the model. However, given the small number of cows with available BCS, 
further investigation into the effect of DD on BCS may be warranted. If excess body condition were associated with dry periods $>60 \mathrm{~d}$, it might also account for the higher culling rates and shorter DIM associated with dry periods $>60 \mathrm{~d}$ by leading to additional health or reproductive problems.

Some investigators might argue that dry periods $>60 \mathrm{~d}$ are not of much interest. However, it has been shown that DO accounts for a significant percentage of the within herd variation in DD, with cows having long DO also having dry periods $>60 \mathrm{~d}$ [15]. Perhaps it is, then, that dairy farmers are forced into keeping cows that are difficult to breed back in order to maintain herd size. Thus, further investigation of dry periods $>60 \mathrm{~d}$ might benefit the dairy producer by providing recommendations on how to manage cows for long dry periods. If BCS, for example, was found to be higher for cows with long dry periods and the excess body condition, in turn, led to other health or reproductive problems in the following lactation, perhaps nutritional recommendations could be formulated for cows expected to have dry periods $>60 \mathrm{~d}$. This improved management might reduce some of the problems (higher culling, fewer DIM, slightly lower milk yield) associated with DD $>60$.

\subsection{Restriction on available data}

One consideration in this study is that lactations where the cow was culled prior to first test-day were not available. For example, if a cow calved into her second (or later) lactation and was culled, say, $14 \mathrm{~d}$ after calving, before the tester visited the herd, her "record" would not have been in the data set. If information on such lactations had been available, one approach to using them would have been to set the lactational record to, basically, zero and then include it, along with its DD, in the data for analysis. Such an approach, however, would probably be more appropriate or more important for analysis of lifetime yield where the intent would be to study not only yield per lacta- tion but DD effects on number of lactations (herd life) as well. With respect to DD effects on lactational yield, "survival to first test-day" might, appropriately, be considered an important but separate trait. The DD effects on lactational yield, estimated in this study, are for cows surviving to first testday.

\subsection{Comparison of results to previously published research}

Results of this study were in general agreement with previously published research [4, 10]. Virtually all DD research published since 1970, whether designed trials or observational studies, has found lower milk yield in the subsequent lactation following dry periods of $<60 \mathrm{~d}$, although differences could not be declared statistically significant in a number of designed trials. Most research has also supported a 40 to $60 \mathrm{~d}$ dry period to maximize milk yield in the subsequent lactation $[4,10]$.

It is somewhat difficult to compare published research to the results found in this study because very few studies have utilized actual lactational production. Several designed experiments [2, 11, 19, 20, 24] have reported differences in actual yield in terms of yield per d but only for a limited part of the lactation which makes extrapolation difficult, especially since cows from shorter dry period groups may not have made it to a given number of DIM.

Cows with 20 or fewer DD averaged 329 DIM in this study. Thus, the results in Table IV for second lactation imply $7.2 \mathrm{~kg}$ per d less milk for dry periods shorter than $21 \mathrm{~d}$, compared to dry periods of 61 to $65 \mathrm{~d}$. This is higher than the $4.1 \mathrm{~kg}$ per d lower milk yield, reported by Remond et al. [20] for $0 \mathrm{vs}$. $60 \mathrm{DD}$ but is lower than the $8.5 \mathrm{~kg}$ per $\mathrm{d}$ for 0 vs. $56 \mathrm{DD}$ reported by Rastani et al. [19].

Cows in this study with dry periods between 21 and $80 \mathrm{~d}$ averaged 345 DIM. Thus, cows with dry periods between 21 and $35 \mathrm{~d}$ averaged about $3.6 \mathrm{~kg}$ per d less milk 
yield than cows with 61 to 65 DD (Tab. IV). This is in good agreement with the results of Sorenson and Enevoldsen [24] who reported $3.1 \mathrm{~kg}$ per d lower milk yield for cows with 4 wk vs. 10 wk dry periods. Rastani et al.'s [19] $4.5 \mathrm{~kg}$ per d loss for cows with 28 vs. 56 DD was somewhat higher but they had production only through the first $70 \mathrm{~d}$ of lactation. In the experiment of Gulay et al. [11], cows with 60 DD produced $2 \mathrm{~kg}$ per d more than cows with 30 DD through the first $10 \mathrm{wk}$ of production, although there was essentially no difference using production through 21 wk of lactation. Comparing $60 \mathrm{DD}$ to $30 \mathrm{DD}$, Annen et al. [2] reported $5.8 \mathrm{~kg}$ per d lower yield in second lactation for cows with only $30 \mathrm{DD}$ and a smaller difference of only $1.1 \mathrm{~kg}$ per $\mathrm{d}$ for multiparous cows. With smaller subclass sample sizes, some variation in the magnitude of these differences is, of course, expected but the direction of difference has generally been consistent.

Bachman [3] appears to have found the smallest differences in lactational yield between DD groups with only a $191 \mathrm{~kg}$ advantage in $305 \mathrm{~d}$ yield for cows with 60 DD compared to cows with 30 DD and the ME milk yield was actually higher for the $30 \mathrm{~d}$ dry period cows. Although none of the differences reported by Bachman [3] were statistically significant, the result of higher ME milk yield for the shorter dry period group appears to be unique. Results of Kuhn and Hutchison [14], however, showed that mean differences in the opposite direction of true differences are not unlikely when group sizes are small; with repeated sampling (experimentation), this is actually expected to occur occasionally. Thus, since the 2 groups without estrogen treatment [3] had only 19 (60 DD) and 15 (30 DD) cows, the higher ME yield of the 30 d dry period cows reported by Bachman [3], could have easily been due to chance alone.

Coppock et al. [6] reported that cows with 10 to $30 \mathrm{DD}$ produced $636 \mathrm{~kg}$ less milk for "complete lactation yield" than cows with 50 to 70 DD. It appears, however, that "complete lactation" meant that records less than $305 \mathrm{~d}$, if allowed, were extended to $305 \mathrm{~d}$. Their estimates, therefore, would be expected to be smaller in magnitude than those reported here since actual yields in this study were not extended to $305 \mathrm{~d}$.

Several observational studies have also been published since 1970. Schaeffer and Henderson [22] found that 50 to 59 DD maximized subsequent lactation 305 d yield but that there was little practical difference for dry periods of 40 to $49 \mathrm{~d}$ or 60 to $69 \mathrm{~d}$. The ME results for second lactation in Table VIII compare reasonably well to the ME results of Funk et al. [9]. The results of Makuza and McDaniel [12] for U.S. cows were similar to the ME results in Table VIII. Although Makuza and McDaniel [12] utilized actual yields, they required a minimum of 250 DIM. Thus, their effects would be expected to be smaller than those reported for actual yields in this study.

Both Funk et al. [9] and Makuza and McDaniel [12] concluded that effects of DD did not depend on parity, but neither presented results for more than 1 lactation. Dias and Allaire [8] appears to be one of the very few studies to look at whether dry period to maximize yield depended on anything other than parity. In contrast to this study, however, Dias and Allaire [8] aimed to determine the dry period length that maximized daily yield across 2 adjacent lactations. They concluded: (1) cows with longer calving intervals need fewer DD than cows with shorter calving intervals, (2) older cows require fewer DD than younger cows, and (3) high producing cows need longer dry periods than lower producing cows. The overall results of Dias and Allaire [8] are in good agreement with the interaction results found in this study.

\subsection{Planned vs. unplanned dry period lengths in observational studies}

The recent renewal of interest in dry period length has brought with it widespread 
condemnation of observational studies, both in the scientific literature $[4,19]$ and in the popular press [16-18]. A common criticism has been that the short dry periods for cows in field data were "unplanned" and therefore the cows were not "managed" for a short dry period. This contention necessarily implies that there are management practices that could either partially or completely offset the production losses associated with shortened DD. If this is not the implication, then the planned vs. unplanned argument is irrelevant.

The first aspect of this argument to be considered, then, is whether or not such management practices do indeed exist. It appears that this is an unproven assumption. As indicated in the previous section, results from designed studies are in general agreement with the main effect results from this study. Sorensen and Enevoldsen [24], for example, described specific management for dry periods of planned lengths and still found milk yield losses of 2 to $3 \mathrm{~kg}$ per d using only the first $84 \mathrm{~d}$ of production, and their results would not have reflected any effects that dry period length may have had on culling or lactation length in the subsequent parity.

Let it now be assumed that management practices do in fact exist that can eliminate, or at least appreciably reduce, milk yield losses caused by shortened dry periods; i.e., let the legitimacy of the "planned vs. unplanned" argument be assumed. The requirement that cows be within $10 \mathrm{~d}$ of their expected calving dates assured that the producers knew, at least at one point in time, when the cows were going to calve because they, in effect, reported it to DHI. Nonetheless, critics speculate that the preponderance of short dry periods in this study (say $<40$ d) were still unplanned, occurring because the producer overlooked the expected calving dates of these cows. This speculation, however, is not particularly tenable. First, there are U.S. herds that have averaged DD $<60 \mathrm{~d}$ and even $<40 \mathrm{~d}$ since 1997 [15]. Furthermore, factors other than chance contribute to within herd variation in DD [15]. Even for herds averaging, for example, 40 to $60 \mathrm{DD}$, intentional variation in DD is introduced based on factors such as milk yield, DO, SCS, and, perhaps, current number of cows milking in the herd.

\subsection{Further research}

Further research should focus on the effects of DD on other traits such as fat and protein yield, fat and protein percent, female fertility (e.g., DO), SCS, and other health traits. Very little research appears to be available for these characteristics but it is important to assess how they are affected by dry period length since they too affect profitability.

While determination of DD effects on subsequent lactation is useful and informative, it is also true that production in the previous lactation is sacrificed by dry off. Additional studies, similar to that of Dias and Allaire [8], should also be done to determine DD that maximizes production across adjacent lactations. However, even that does not address the question of whether short dry periods might shorten herd life. Thus, future research should also aim to determine the dry period length that maximizes lifetime performance. Once more complete information on other economically important traits and on lifetime performance has been assembled, an economically optimum dry period could be determined.

Finally, perhaps additional studies, similar to that of Capuco et al. [5], could be done to determine biological bases for some of the results found in this study. Although many researchers may argue that dry periods longer than $60 \mathrm{~d}$ are not of much interest, long dry periods certainly occur in practice and determination of how this affects the mammary gland might be instructive. Determination of why, biologically, cows with long DO would be less affected by shortened dry periods than cows with shorter open periods and how this interacts 
APPENDIX. Main effect of days dry on actual milk adjusted for days in milk (DIM) and on matureequivalent milk yield for lactations 3 and $4^{1}$.

\begin{tabular}{crrrrrr}
\hline \multirow{2}{*}{$\begin{array}{c}\text { Days dry } \\
\text { category }\end{array}$} & $\begin{array}{c}\text { Days } \\
\text { dry }\end{array}$ & \multicolumn{2}{c}{ Actual Milk $^{2}(\mathrm{~kg})$} & & \multicolumn{2}{c}{$\mathrm{ME}^{2}(\mathrm{~kg})$} \\
\cline { 3 - 4 } \cline { 6 - 7 } \cline { 6 - 7 } & $0-10$ & -1625 & -1528 & & Parity $3^{4}$ & Parity $4^{4}$ \\
\hline 1 & $11-20$ & -1711 & -1447 & & -1031 & -889 \\
3 & $21-30$ & -1041 & -1091 & & -624 & -997 \\
4 & $31-35$ & -770 & -718 & & -424 & -664 \\
5 & $36-40$ & -622 & -717 & & -346 & -406 \\
6 & $41-45$ & -455 & -476 & & -247 & -423 \\
7 & $46-50$ & -330 & -331 & & -164 & -181 \\
8 & $51-55$ & -211 & -190 & & -107 & -97 \\
9 & $56-60$ & -85 & -55 & & -42 & -8 \\
10 & $61-65$ & 0 & 0 & & 0 & 0 \\
11 & $66-70$ & -3 & 13 & & -34 & 5 \\
12 & $71-80$ & -55 & -13 & & -76 & -65 \\
13 & $81-90$ & -38 & 18 & & -126 & -81 \\
14 & $91-100$ & -18 & 43 & & -133 & -176 \\
15 & $101-110$ & 0 & 91 & & -174 & -103 \\
16 & $111-120$ & 99 & 83 & & -148 & -188 \\
\hline
\end{tabular}

${ }_{1}$ All analyses were on records with a prior correction for cow effects and with previous lactation yield in the model.

2 Difference in milk yield: days dry category $i$ minus days dry category 10 , where $i=1$ to 16 .

${ }^{3}$ Model [1], plus DIM included as a covariate.

${ }^{4}$ Model [1] using mature-equivalent milk yield.

with level of production could also be informative and may enhance the ability to formulate appropriate management recommendations.

\section{CONCLUSIONS}

Results of this study were in general agreement with most previously published research. A dry period of $60 \mathrm{~d}$ maximizes milk yield in the subsequent lactation, regardless of parity, or level of milk yield, age at calving, SCS, or DO in the previous lactation. Dry periods less than $20 \mathrm{~d}$ result in very pronounced losses in subsequent lactation yield. Dry periods of more than 70 or $80 \mathrm{~d}$ also result in lower milk yield in the subsequent lactation, although the effect is considerably smaller than for short DD. It appears, based on limited data, that excess body condition does not account for the lower production associated with long DD.

Although DD to maximize subsequent lactation yield does not depend on any factors examined in this study, younger cows do experience greater losses with short dry periods than do cows that first calved at an older age. It appears that short dry periods are also more detrimental for high production cows and for cows with lower SCS. Furthermore, short dry periods are more detrimental for cows that conceived early in lactation than for cows with longer DO, at least in first lactation. In general, better cows pay a larger price for shortened dry periods than poorer cows. 
Use of actual milk yields for investigation of DD effects reveals variation due to DD that is obscured by use of standardized records. Use of actual records led to the discovery that lactation length is shorter for cows with extreme dry periods, either short or long. Part of this difference in DIM may be related to culling since cows in the extremes for dry period length were also culled more intensely than cows with dry periods between 40 and $70 \mathrm{~d}$.

Further research should focus on additional traits of economic importance and on determining dry period length to maximize yield across adjacent lactations and lifetime yield. Research to determine the biological bases for results found may further enhance appropriate management of dry period length.

\section{ACKNOWLEDGEMENTS}

The authors thank Anthony Capuco as well as Paul VanRaden and Curt VanTassel for helpful discussions. Helpful reviews and comments were provided by Mike Schutz and Bob Miller. Ignacy Misztal is also gratefully acknowledged for the use of his BLUPF90 program as is Tianlin Wang, Rohan Fernando, and Steve Kachman for the use of their Matvec software. We would also like to thank Johanne Detilleux and Bernard Remond for their assistance with the French "résumé".

\section{REFERENCES}

[1] Animal Improvement Programs Laboratory, Trend in milk breeding values for Holstein calculated August, 2004. [Online] Available: http://aipl.arsusda.gov/dynamic/trend/current/ trndx.html [Accessed Aug. 30, 2004].

[2] Annen E.L., Collier R.J., McGuire M.A., Vicini J.L., Ballam J.M., Lormore M.J., Effect of modified dry period lengths and bovine somatotropin on yield and composition of milk from dairy cows, J. Dairy Sci. 87 (2004) 3746-3761.

[3] Bachman K.C., Milk production of dairy cows treated with estrogen at the onset of a short dry period, J. Dairy Sci. 85 (2002) 797-803.
[4] Bachman K.C., Schairer M.L., Invited Review: Bovine studies on optimal lengths of dry periods, J. Dairy Sci. 86 (2003) 30273037.

[5] Capuco A.V., Akers R.M., Smith J.J., Mammary growth in Holstein cows during the dry period: Quantification of nucleic acids and histology, J. Dairy Sci. 80 (1997) 477-487.

[6] Coppock C.E., Everett R.W., Natzke R.P., Ainslie H.R., Effect of dry period length on Holstein milk production and selected disorders at parturition, J. Dairy Sci. 57 (1974) 712-718.

[7] Dechow C.D., Rogers G.W., Clay J.S., Heritability and correlations among body condition score loss, body condition score, production and reproductive performance, J. Dairy Sci. 85 (2002) 3062-3070.

[8] Dias F.M., Allaire F.R., Dry period to maximize milk production over two consecutive lactations, J. Dairy Sci. 65 (1982) 136-145.

[9] Funk D.A., Freeman A.E., Berger P.J., Effects of previous days open, previous days dry, and present days open on lactation yield, J. Dairy Sci. 70 (1987) 2366-2373.

[10] Grummer R.R., Rastani R.R., Why reevaluate dry period length? J. Dairy Sci. 87 (2004) E77-E85.

[11] Gulay M.S., Hayen M.J., Bachman K.C., Belloso T., Liboni M., Head H.H., Milk production and feed intake of Holstein cows given short (30-d) or normal (60-d) dry periods, J. Dairy Sci. 86 (2003) 2030-2038.

[12] Makuza S.M., McDaniel B.T., Effects of days dry, previous days open, and current days open on milk yields of cows in Zimbabwe and North Carolina, J. Dairy Sci. 79 (1996) 702709 .

[13] National Agricultural Statistics Service, Agriculture Statistics. [Online] Available: http:// www.usda.gov/nass/pubs/agstats.htm [Accessed Aug. 30, 2004].

[14] Kuhn M.T., Hutchison J.L., Methodology for estimation of days dry effects, J. Dairy Sci. 88 (2005) 1499-1508.

[15] Kuhn M.T., Hutchison J.L., Norman H.D., Characterization of Days Dry in United States Holsteins, J. Dairy Sci. 88 (2005) 1147-1155.

[16] Linderoth S., Decrease dry periods by 20 days. Dairy Herd Management. [Online] Available: http://www.dairyherd.com [Accessed Oct. 12, 2004]. 
[17] Mohr P., 60 days dry - says who? Dairy Today. [Online] Available: http://www.agweb.com/ pub_get_article.asp?sigcat=dairy\&pageid=106373 [Accessed Oct. 12, 2004].

[18] Rastani R., Grummer R., Shorter dry periods look good, Hoard's Dairyman 148 (2003) 599.

[19] Rastani R.R., Grummer R.R., Bertics S.J., Gumen A., Wiltbank M.C., Mashek D.G., Schwab M.C., Reducing dry period length to simplify feeding transition cows: milk production, energy balance, and metabolic profiles, J. Dairy Sci. 88 (2005) 10041014.

[20] Rémond B., Ollier A., Miranda G., Milking of cows in late pregnancy: milk production during this period and during the succeeding lactation, J. Dairy Res. 59 (1992) 233241.

[21] Sargent F.D., Lytton V.H., Wall O.G. Jr., Test interval method of calculating dairy herd improvement association records, J. Dairy Sci. 51 (1968) 170-179.

[22] Schaeffer L.R., Henderson C.R., Effects of days dry and days open on Holstein milk production, J. Dairy Sci. 55 (1972) 107-112.

[23] Shook G.E., Johnson L.P., Dickinson F.N., Factors for improving accuracy of estimates of test-interval yield, DHI Lett. 56 (1980) 924.

[24] Sorensen J.T., Enevoldsen C., Effect of dry period length on milk production in subsequent lactation, J. Dairy Sci. 74 (1991) 12771283

[25] Waltner S.S., McNamara J.P., Hillers J.K., Relationships of body condition score to production variables in high producing Holstein dairy cattle, J. Dairy Sci. 76 (1993) 34103419. 